\title{
Turboslované a jiné fantazie, aneb historik a pseudověda
}

\section{ANDRZEJ SPYRA}

Spyra, Andrzej: The Turbo-Slavs and other Fantasies or Historian and Pseudoscience

The article is an attempt to tackle the question of pseudoscience in a modern world. The author starts his essay with the problem of the so-called "turbo-slavs", but progressively goes on to capture a wider view of similar cases of misusing sources to achieve certain goals. The starting point for this is the history of the fake Chronicle of Prokosz, which became the basis of the pseudo-scientific theory of Great Lechia. From the author standpoint, observed phenomenona are not only problems by themself, but also symptoms of deeper problems afflicting modern society.

Key Words Chronicle of Prokosz; Turbo-Slavs; Pseudoscience; Conspiracy Theories; Sociology

doi.org/10.15452/Historica.2020.11.0010

Contact Uniwersytet Humanistyczno-Przyrodniczy im. Jana Długosza w Częstochowie; andrzej.spyra@gmail.com

Ještě před několika lety by se zdálo, že nejstarší historické dějiny středoevropských státních organismů jsou dobře prozkoumány a nevyvolávají mnoho kontroverzí ani emocí. Ukazuje se však, že v posledních několika letech si v Polsku získává stále větší popularitu pseudohistorická teorie založená zejména na padělku z 19. století, podle níž předci dnešních Poláků vytvořili mocnou Lechickou říši tisíce let před dobou prvních historických Piastovců. Prozkoumání historie samotného falzifikátu a mechanismů této pseudohistorické teorie může vrhnout trochu světla nejen na tuto teorii, ale také na další pseudovědecké názory.

Z pohledu historika je obzvlášt zajímavá skutečnost, že v rozporu se současným stavem poznání roste popularita teorií o tom, že ve druhém tisíciletí před naším letopočtem v oblasti široce chápaného území západních a východních Slovanů existovalo mocné impérium, které se úspěšně bránilo Peršanům či útokům Alexandra Velikého a Římanů. O tom, jak je tento fenomen rozšířený, svědčí náklady publikací věnovaných této tematice i bohatá činnost stoupenců těchto teorií, kteří jsou aktivní na desítkách internetových stránek a diskusních fór a zveřejňují na videoportálech nahrávky, v nichž propagují své představy o světě.

Tato esej si neklade za cíl rozložit jednotlivé pseudohistorické, nebo v tomto případě „turboslovanské“ teorie na prvočinitele; to už před námi učinili jiní. ${ }^{1}$ Namísto toho se pokusíme, především na případu tzv. Velké Lechie, prozkoumat mechanismus, který za nimi stojí, a najít odpověd' na otázku, jak jsou tyto teorie vystavěné, jestli mají navzájem něco společného a zda nám podobné pseudovědecké teorie mohou něco sdělit o naší současnosti.

\footnotetext{
1 Viz ŻUCHOWICZ, Roman: Wielka Lechia : Źródła i przyczyny popularności teorii pseudonaukowej okiem historyka. Warszawa 2018.
} 
Nesnadný je již samotný úkol definovat termín „pseudověda“, protože se nejedná o pouhé odmítání vědy nebo nevědeckost. Pseudovědecké teorie nerespektují pravidla vedení výzkumu v daném oboru a jsou v rozporu se současným stavem poznání, ale přesto aspirují na to, aby byly označovány za vědecké, takže např́iklad používají jazykový styl běžný ve vědeckých publikacích nebo odkazují na vybraná fakta. Vědec, jehož teze jsou při zachování pravidel vědeckého diskursu vyvráceny, své teze změní. Vyznavač pseudovědy při konfrontaci s fakty, která jsou v rozporu s jeho teoriemi, jen pokrčí rameny. Podle Karla Poppera můžeme konstatovat, že zatímco věda neustále ověřuje práci mnoha generací vědců, pseudověda potvrzuje vlastní předpoklady. ${ }^{2}$ Pseudovědci také často tvrdí, že je jejich práce natolik průkopnická, že představuje zcela novou kvalitu ve vědě, která jednoduše ještě nedozrála k tomu, aby akceptovala jimi postulované teze, ale po čase jim bude muset dát za pravdu. Je to pohodlná výmluva, protože v hávu vizionáře je snadné odrážet kritické hlasy ze strany skutečně vědeckého prostředí tvrzeními v duchu toho, že vizionáři byli vždy ve své době nepochopeni a že „nezávislé výzkumy“ pseudovědců jednoduše ohrožují pozici „oficiálních“ akademiků, kteří - v tomto případě na pokyn Vatikánu „falšují pravdivou historii“. Ne bezdůvodně nalezneme na obálkách knih Janusze Bieszka, který je v určitých kruzích v Polsku populární, tvrzení, že se jedná o první publikaci pojednávající o systému vlády a fungování Lechie, a na obálce Prokošovy kroniky, kterou připravuje do tisku, je umístěn citát mylně připisovaný Mahátmovi Gándhímu. ${ }^{3}$

\section{Na počátku byl žert}

V roce 1817 ve věži kostela ve Dvoře Králové mladý ambiciózní filolog Václav Hanka objevil Rukopis královédvorský, který později posloužil při budování českého národního uvědomění. Přibližně ve stejné době nalezl generál Franciszek Morawski na tržnici v Lublinu rukopis, který měl popisovat nejstarší dějiny Polska. Tyto dva dokumenty se liší v tom, že zatímco Rukopis královédvorský byl v rámci tzv. sporu o Rukopisy, který probíhal v letech 1886-1888, všeobecně uznán za dovednou mystifikaci Václava Hanky a Josefa Lindy, Prokošova kronika, objevená Morawským, byla po léta považována pouze za zajímavost z poznámky pod čarou v životopise Joachima Lelewela, který ji hned po jejím vydání označil za podvrh. A tak by to bezpochyby zůstalo, kdyby nebyla v 21. století oprášena a nestala se jedním z pilířu pseudovědecké teorie o Velké Lechii.

Základem tohoto konstruktu je především výše zmíněná tzv. Prokošova kronika, která poprvé vyšla tiskem v roce 1825 ve Varšavě, doplněná o nezřídka chybně uváděné zdroje vybrané tak, aby podporovaly teze autorů, dále pak selektivně pojatá archeogenetika a nepochopení toho, že významový obsah, tak jak mu rozumíme dnes, získal pojem národ v 19. století. Jelikož je však Prokošova kronika ústřední součástí tohoto konstruktu, podívejme se na ni blíže. První vydání tohoto díla vyšlo nákladem generála Franciszka Morawského. Tento voják, plodný literát a uznávaný kritik byl zároveň objevitelem rukopisu kroniky. Příběh neobvyklého nálezu je popsán v předmluvě k prvnímu vydání Prokošovy

\footnotetext{
2 POPPER, Karl: Science as Falsification. In: TÝŽ: Conjectures and Refutations. London 1963, s. 33-39. Online, cit. 22.1. 2019 dostupné na https://staff.washington.edu/lynnhank/Popper-1.pdf.

3 Slavná slova Nejdř́v tě budou ignorovat. Pak se ti budou smát. Pak proti tobě budou bojovat. Potom zvítězíš, nepronesl Gándhí. Tento údajný citát, v mírně pozměnění podobě, pochází z projevu, který v roce 1918 přednesl americký advokát a odborářský aktivista Nicholas Klein. Srov. Proceedings of the biennial convention of the Amalgamated Clothing Workers of America, held in Baltimore, Maryland May 13 to 181919, s. 53. Online, cit. 15. 10. 2019 dostupné na https://archive.org/details/generalexecuti1919amaluoft/page/52.
} 
kroniky. Podle něj generál Morawski nalezl text v Lublinu v jednom židovském obchodě, kde byly staré pergameny používány k balení drobného zboží. Morawski jej koupil a odeslal do Královské varšavské společnosti přátel nauk. Ediční práce na takto zázračně nalezeném díle byla následně svěřena historikovi Hipolitu Kownackému. Ten při přípravě díla k tisku vypreparoval z rukopisů to, co považoval za text Prokošovy kroniky, a snažil se oddělit původní text od přidaných fragmentů z kroniky spisovatele z 11. století Kagnimira a od kritických poznámek komentátora $z$ 18. stolení, které měly být vloženy mezi text původního autora. ${ }^{4}$ Výsledkem měla být, jak by si přáli stoupenci teorie Velké Lechie, perla nejstarších kronik, protože je dokumentačně nejobsáhlejší, nejpřesnější a podrobně popisuje období starověku a raného středověku, zpracované do logického, chronicky uspořádaného sledu událostí a vlád panovníkủ, tak jak ho potvrzují další naše kroniky. ${ }^{5}$ Autorem této „perly“ měl být první krakovský arcibiskup Prokoš, zvaný též Prochorus či Procosius, který ji údajně napsal v 10 . století.

Pokud by tento objev byl pravý, jednalo by se o skutečnou senzaci. Objevily se však určité pochybnosti. Především šlo o to, že Prokoš měl být nejen prvním krakovským arcibiskupem, ale také benediktinem. Problém je však v tom, že v té době na polském území benediktinský řád nepůsobil a Krakov nebyl arcibiskupstvím. Autor rovněž nemohl psát o svých nástupcích, ale přesto to udělal. Editor prvního vydání si rovněž všímá toho, že rukopis, který se k němu dostal, byl napsán polsky, ${ }^{6}$ vysvětluje to však tím, že text byl nepochybně $\mathrm{v}$ průběhu staletí přeložen $\mathrm{z}$ latiny některým $\mathrm{z}$ komentátorů, a tak se šíril v opisech, až se jeden z nich dostal do onoho lublinského obchodu. ${ }^{7}$

$\mathrm{V}$ nejlepším případě by se tedy jednalo o středověký falzifikát vydávající se za text údajného Prokoše. Ale ani to nelze obhájit. Jako první se zpochybněním pravosti zabýval Joachim Lelewel, který si povšiml dalších nepřesností. Upoutaly ho mimo jiné takové „detaily“, jako jsou volby v dobách prvních Piastů, nepotvrzené žádnými jinými zdroji, nebo to, že se v textu běžně vyskytují erby, které se v té době nepoužívaly, zejména erb Širočina (Topór). A jako by toho nebylo málo, Lelewel objevil ještě jinou kopii domnělé kroniky, kterou měl v druhé polovině 17. století přepsat Przybysław Dyamentowski. Zkušený historik vynaložil úsilí potřebné ke zjištění, kdo byl zmiňovaný Dyamentowski. Podle informací, které Lelewel získal, „tento Przemysław Dyamentowski, který zastával úřad stolníka, zemřel v roce 1774 ve svých osmdesáti letech. Zanechal po sobě svého jediného syna Sobiesława, který byl nezletilý a jehož opatrovníkem byl Bartosiewicz. Tento Bartosiewicz dal celou truhlu Przybysławových rukopisů Felixovi Łubieńskému, pozdějšímu ministru spravedlnosti varšavského knížectví, a tyto rukopisy byly uloženy v Guzowě. U Dyamentowského byla tedy, dalo by se říci, dílna, nebo prinejmenším skladiště podivných a príšerných historických výplodů. ${ }^{8}$ Těmito př́íernými výplody byla samozrejmě další „stará“ díla autorů jako Wojan, Kagnimir či Świętomir, což společně s dalšími

\footnotetext{
$4 \quad$ ŻUCHOWICZ, R.: Wielka Lechia, s. 31.

$5 \quad$ BIESZK, Janusz: Stowiańscy królowie Lechii. Warszawa 2015, s. 124.

6 Kownacki toto dílo přeložil do latiny a vydal tiskem pod názvem Chronicon Slavo-Sarmaticum Procosii saeculi X. scriptoris atque de origine Toporeorum ex libris Zolavi et Kagnimiri saeculi XI. scriptorum excerpta. Varsaviae 1827.
}

7 ŻUCHOWICZ, R.: Wielka Lechia, s. 32.

8 LELEWEL, Joachim: Rozbiory Dziet, 1. Poznań 1844, s. 198. 
indiciemi ukazovalo na to, že Prokošova kronika je podvrh. Lelewel se dokonce pokusil kroniku datovat a umístil její vznik mezi léta 1711 a $1730 .^{9}$

Lelewel př́mo neoznačil Dyamentowského za autora Prokošovy kroniky, na rozdíl od Michała Wiszniewského, který se touto otázkou zabýval o něco později. ${ }^{10}$ Zjištění obou vědců byla po téměř dvě století považována za nesporná. ${ }^{11}$ Ale pouze do té doby, než na počátku 21. století došlo ke dvěma událostem: Prokošova kronika byla propagátory Velké Lechie nekriticky prohlášena za „perlu“ a Piotr Boroń ${ }^{12}$ postuloval ještě jednu hypotézu o jejím vzniku.

Důvody, které vedly propagátory k teorii Velké Lechie, se budeme zaobírat na jiném místě. Pokud jde o Boroně, zdálo se mu podezřelé, že Dyamentowski neměl v podstatě žádný logický důvod pro to, aby vytvořil falsifikát kroniky. Podezřelé se mu zdálo také to, že po zveřejnění rukopisu nalezeného v Lublinu objevil Lelewel ve Vilniusu druhou kopii tohoto díla, kterou použil jako důkaz nepravosti kroniky. To je skutečně zvláštní souhra náhod, vezmeme-li v úvahu, že žádné další kopie Prokošovy kroniky nebyly již nikdy nalezeny. Po analýze mnoha dostupných pramenů postuluje Boroń tezi, že za vznikem tzv. Prokošovy kroniky stojí její objevitel Franciszek Morawski. A důvodem, proč Morawski věnoval celé záležitosti takové úsilí, byla podle něj jednoduše nuda. Boroń upřesňuje, že generál, který za napoleonských válek procestoval celou Evropu a býval návštěvníkem slavných salonů, pocitoval v provinčním Lublinu, kde velel pěchotní posádce, nesnesitelnou nudu. Jednou z jeho nemnoha kratochvílí bylo překládání poezie a tropení si žertů z kolegy v překladatelském řemesle Kajetana Jaxy-Marcinkowského, kterému se ř́kalo Jaxa. ${ }^{13}$ Jaxa podle soudobých zpráv nebyl ani talentovaný, ani př́liš bystrý na duchu, zato byl neobyčejně namyšlený a sebejistý, a proto byl častým objektem výsměchu a žertů. Jak napsal Kajetan Koźmian, Marcinkowski byl tak podivným, nepochopitelným a nenapravitelným stvořením, že se dnes každý, kdo se podívá na jeho portrét v jediné póze při deklamaci, jak ho umně zachytil štětec Sokołowského, musí chtě nechtě rozesmát. Jak bychom tedy mohli vyčitat smích a žerty všem těm, kterým se jeho živoucí osobnost prímo nabízela a v nejrůznějších pozicích, jedna směšnější než druhá, se jim neustále zjevovala před očima? ${ }^{14}$

Morawski poznal Jaxu ve Varšavě a pozval ho k sobě do Lublinu, kde se Jaxa stal předmětem jeho neustálých žertů. Generál ho mimo jiné přesvědčil, aby uvedl svou naprosto nepodařenou hru Orsej (Pszonka), kterou prý Morawského podřízení odměnili živelným potleskem. Toto představení mělo způsobit, že Jaxa uvěřil, že má talent. Jindy zase Morawski zařídil, aby byl Jaxovi zaslán podvržený dokument, který mu sděloval přidělení důležitého úřadu. Když se pak Jaxa-Marcinkowski začal svým jmenováním vychloubat, byl mu původní jmenovací dopis z obálky ukraden a místo něj byl vložen stejný, avšak podepsaný slovy hlavní ministr špitálu blbečků. A jak to vše souvisí s Prokošovou kronikou? Boroń tvrdí, že vznikla jako sofistikovaná léčka, jejímž cílem bylo ztropit si žert z Jaxy-Marcinkowského. Morawski, který měl rezervovaný př́stup k tehdy módnímu hledání

\footnotetext{
9 Tamtéž, s. 197.

10 WISZNIEWSKI Michał: Historya literatury polskiej, 2. Kraków 1840, s. 181.

11 ŻUCHOWICZ, R.: Wielka Lechia, s. 41.

12 Viz BOROŃ, Piotr: Uwagi o apokryficznej kronice tzw. Prokosza. In: ROSIK, Stanisław - WISZEWSKI, Przemysław (eds.): Ad fontes : O naturze źródła historycznego. Wrocław 2004, s. 363-374.

13 BOROŃ, P.: Uwagi, s. 370

14 KOŹMIAN, Kajetan: Pamiętniki Kajetana Koźmiana :Oddział III i ostatni. Kraków 1865, s. 353.
} 
starých rodokmenů, si chtěl vystřelit $\mathrm{z}$ vychloubačného a zároveň důvěřivého Marcinkowského z rodu s erbem Širočina (Topór). Pro tuto tezi hovoří nejen neobvykle častý výskyt představitelů tohoto rodu v textu údajné kroniky, ale také generálovy společenské vazby, které autor detailně analyzoval, a stopy této léčky v dochované generálově korespondenci. Franciszek Morawski měl motiv, schopnosti i možnosti, aby krátce před rokem 1825 realizoval společenský žert, jehož objektem se měl stát Kajetan Jaxa-Marcinkowski. Podle této koncepce měl být skeptický Lelewel přiveden na stopu druhé kopie textu proto, aby zesměšnil Jaxu, který se pravděpodobně - jak se dá usuzovat na základě jeho dřivějšího chování - začal vychloubat stárím svého rodu, který měl mít počátky ještě v dobách pred prvními Piastovci. ${ }^{15}$

\section{Falešný dokument, chybná diagnóza}

Nejedná se samozřejmě o první, a nepochybně ani poslední případ využití zfalšovaného historického dokumentu za nějakým konkrétním účelem. Snaha společensky zesměšnit důvěřivého známého $\mathrm{v}$ době, kdy bylo $\mathrm{v}$ módě hledat své starodávné kořeny, je pochopitelná. Je také pochopitelné, že v této době byly vytvářeny nejrůznější „památky“, jejichž úkolem měla být podpora tehdy ještě slabého národního uvědomění v jeho dnešním pojetí. Tento jev byl ostatně rozšířený v celé Evropě a neomezoval se na pouhé falsifikáty, jejichž autorem byl Hanka zmiňovaný na počátku této práce. ${ }^{16}$ Důvody, proč se různé osoby uchylovaly $k$ tomuto typu činností například v rámci utváření moderně chápaného národního uvědomění, jsou pro dnešního historika pochopitelné. Totéž se však nedá říci o snahách vytvářet neexistující minulost, jaké můžeme pozorovat dnes. Proč se tedy něco, co spatřilo světlo světa na začátku 19. století jako společenský žert, stalo téměř o dvě stě let později základem pseudovědecké teorie?

Mohli bychom se samozřejmě pokusit hledat odpověd' na tuto otázku v motivaci lidí, kteří vytvořili tu pseudovědeckou teorii, a snažit se tuto motivaci pochopit. Pak by bylo třeba zjistit, zda skutečně věří tomu, že existovala Velká Lechie, nebo zda je můžeme obvinit z vypočítavosti a z toho, že je jejich konání motivováno snahou o hmotný prospěch (jejich publikace se koneckonců prodávají), anebo začít hledat ještě jiný důvod, který je vede $\mathrm{k}$ tomu, aby věnovali čas a prostředky na propagaci svých teorií. Podobné úvahy však nemají větší význam, protože z pohledu historika není ve skutečnosti důležitý důvod, proč někdo hlásá falešný obraz minulosti, ale to, proč mu někdo naslouchá. A z širšího pohledu je podstatná otázka, proč se zdá, že stále více lidí podléhá kouzlu pseudovědy.

Roman Żuchowicz ve své knize věnované fenoménu Velké Lechie připomíná, že lidská mysl nesnese prázdnotu, ${ }^{17}$ a domnívá se, že pseudovědecké teorie o počátcích Slovanů mohou být vyvolány potřebou vyplnit prázdná místa v historii Polska nebo šířeji v dějinách území obývaných Slovany. Prameny týkající se této otázky jsou skutečně velmi omezené a často nám toho dokáže více říci archeologie o tom, s kým lidé obývající v minulosti

\footnotetext{
15 BOROŃ, P.: Uwagi, s. 373-374.

16 Osobou, která „vylepšila“ dějiny Moravy, byl Antonín Boček, viz CISÁR, Vladimír (ed.): Život a dílo prof. Antonína Bočka. Bystřice nad Pernštejnem 2007. O širším, evropském kontextu falšování středověkých manuskriptů v této době pojednává například BAK, János M. - GEARY, Patrick J. - KLANICZAY Gábor (eds.): Manufacturing a Past for the Present : Forgery and Authenticity in Medievalist Texts and Objects in Nineteenth-Century Europe. Leiden 2015.
}

17 ŻUCHOWICZ, R.: Wielka Lechia, s. 241. 
danou oblast udržovali obchodní styky, než historie o jejich politickém systému či o tom, jak se jmenoval jejich panovník. Bílé skvrny na stránkách historie jsou proto naplněny stoupenci teorie Velké Lechie „prameny“ druhu Prokošovy kroniky. Vědecké zjištování fakt je rovněž složité, zatímco pseudovědecké teorie nabízejí snadný způsob, jak toto prázdno vyplnit, a protože nejsou svázány pravidly platnými pro vědecké práce, mohou potenciálním recipientům předložit mnohem atraktivnější obraz minulosti. $\mathrm{V}$ tom se podobají historickým románům či filmům, ale na rozdíl od nich aspirují na to, aby byly považovány za vědecké. ${ }^{18}$

Żuchowicz rovněž navrhuje, že narůstající popularitě pseudovědeckých teorií v oblasti historie je třeba čelit především popularizací vědecky podložených znalostí. Všímá si, že doposud bylo ve vědeckých kruzích psaní populárně naučných textů považováno za neprríliš podstatnou záležitost, to je však třeba změnit, pokud bychom chtěli skutečné vědění předat širšímu publiku. Dalším požadavkem je změna zpo̊sobu výuky dějepisu. Jako argument uvádí, že fakta a data můžeme v dnešní době kdykoli zjistit, ale pochopit, proč o minulosti víme to, co víme, je mnohem těžší. ${ }^{19}$

Tentýž autor navrhuje rovněž, aby aktivní reakce na šíření pseudovědeckých teorií byla dnes zahrnuta do étosu vědce. Podle dosavadní činnosti Żuchowicze v oblasti žurnalistiky by měla tato reakce spočívat v objektivním poukazování na věcné chyby, na nichž jsou uvedené teorie založeny. ${ }^{20}$ Taková věcná kritika však nutně nepřesvědčí stoupence pseudovědecké teorie, kteří takové vysvětlení prostě nemusí akceptovat.

Jiný přístup představuje Michael Morys-Twarowski, historik a také popularizátor vědy, který věří, že úkolem historiků je psát tak, aby bylo možné se skutečnou vědou oslovit co nejširší publikum. V rozhovoru, v němž propaguje svou knihu o expanzívních snahách Boleslava Chrabrého, ${ }^{21}$ autor uvádí, že pokud důvodem popularity teorie Velké Lechie je touha po silné a slavné minulosti, je třeba najít skutečné př́klady a zvýraznit je. Bez ztráty jakýchkoli vědeckých či literárních hodnot. ${ }^{22}$

Oba výše uvedené přístupy jsou v podstatě správné, ale takové diagnózy se neliší od diagnóz uváděných zástupci jiných vědeckých odvětví, která jsou také v poslední době podkopávána pseudovědou, a aktivity realizované na jejím základě zřejmě nepřinášejí větší efekt. Nechceme zde tvrdit, že je třeba rezignovat na popularizaci vědeckého poznání, to je důležité samo o sobě, ani že způsob výuky dějepisu je ideální. Tvrdíme, že změny v této oblasti nemají žádný vztah k příčině problému, tedy k existenci živné půdy pro rozvoj pseudovědeckých teorií. Tento základ se bude podobat kterékoli jiné konspirační teorii, s níž má teorie Velké Lechie mnoho společných prvků. Máme tedy osoby disponující „oficiálním“ věděním, stojící na straně „mocných tohoto světa“, a proti nim „nezávislé badatele“, kteří se staví do opozice k „oficiálním“ stanoviskům a zasvěcují do zjištěných tajemství své recipienty. Pokud problém nahlédneme z této perspektivy, vyjde najevo, že v podstatě není př́liš velký rozdíl mezi „Turboslovany“, vyznavači teorie o tom, že Země je placatá, či o tom, že Země byla v daleké minulosti cílem návštěv mimozemštanů. Není bez

\footnotetext{
18 Tamtéž, s. 245-246.

19 Tamtéž, s. 260.

20 ŻUCHOWICZ Roman: (Pseudo)archeologia o początkach Polski. Archeologia żywa, 2018, č. 4, s. 4-11.

21 MORYS-TWAROWSKI Michael: Narodziny potęgi : Wszystkie podboje Bolestawa Chrobrego. Kraków 2017.

22 MORYS-TWAROWSKI Michael - STACHNIK Paweł: Po co nam wyssana z palca Wielka Lechia, skoro mieliśmy prawdziwe mocarstwo?, Online, cit. 10. 08. 2020 dostupné na https://twojahistoria.pl/2017/09/14/po-co-nam-wyssana-z-palca-wielka-lechia-skoro-mielismy-prawdziwe-mocarstwo/.
} 
důvodu, že největší propagátor Prokošovy kroniky, Janusz Bieszk, předtím, než se ujal teorie Velké Lechie, vydal knihu o údajné přítomnosti mimozemštanů na Zemi v minulosti. ${ }^{23}$

\section{Závěr}

Případ Prokoszovy kroniky je dokonalým př́íkladem toho, jak mohou být historické dokumenty vyňaté ze svého původního kontextu, po několika stoletích, zneužívány. Místo toho, aby tento text byl svědectvím éry, jejíž částí byla produkce nejrůznějších „památek“ a literárních mystifikací, jako např. Ossianovy zpěvy nebo Rukopis královédvorský, se na začátku 21. století stal základem pseudohistorické a pseudovědecké teorie Velké Lechie. Její propagátoři, využívající jak samotný text Prokoszovy kroniky, tak fragmenty dalších děl vyňatých z kontextu, tvrdí, že dlouho před vznikem historického státu prvních Piastovců, oblasti široce pojaté jako Střední a Východní Evropa, byly ovládnuty mocnou Lechickou říší, jejímž přímým dědicem je dnešní Polsko.

Bohužel, kdybychom soudili podle počtu publikací o Velké Lechii a „Turboslovanech“, které se v Polsku objevily v posledních několika letech (Janusz Bieszk publikoval nejen Prokoszovu kroniku, ale ještě tři knihy o Velké Lechii, má také následovníky, kteří rovněž publikují své „nálezy“), téma padlo na úrodnou půdu, což svědčí o určité krizi ve vnímání přesné historické vědy ve společnosti. Pečlivé prozkoumání tohoto fenoménu je nutné, aby mu bylo možné odporovat, zejména proto, že dosud vynaložené úsilí zřejmě nepřesvědčuje stoupence pseudovědeckých teorií. Popularizace znalostí opřených o fakta a psaní populárně vědeckých textů je samo o sobě dobrým nápadem, ale zdá se, že v současném světě, v němž veškeré informace jsou na dosah ruky, nedostatek přístupu k vědě není důvodem rostoucí popularity pseudovědeckých teorií. Historikové mají v této věci omezený prostor - vysvětlení důvodů této popularity bude pravděpodobně vyžadovat důkladný interdisciplinární výzkum, do něhož se budou muset zapojit především psychologové a sociologové. ${ }^{24}$

\section{Summary}

\section{The Turbo-Slavs and other Fantasies or Historian and Pseudoscience}

The act of using false information to achieve own goals is of course not a new phenomenon. The military historians can cite loads of examples of the use of subterfuge to deceive the enemy, but war is not the only area of life in which similar examples can be found. In the case of the so called Chronicle of Prokosz referred in this paper, the impulse to create it was a desire to socially mock flatulent, yet gullible, acquaintance. General Franciszek Morawski, who "discovered" the chronicle and most likely stood behind this hoax, because he had both the motive and the opportunity to organize the discovery of the "ancient" chronicle praising his friend's ancestors, could not have thought that almost two hundred years later, his work

\footnotetext{
$23 \quad$ BIESZK Janusz: Cywilizacje kosmiczne na Ziemi. Warszawa 2014.

24 Tyto studie v omezené míře již probíhají. Viz např. ABALAKINA-PAAP, Marina a kol.: Beliefs in conspiracies. Political Psychology, 20, 1999, s. 637-647, GRZESIAK-FELDMAN, Monika: The effect of high-anxiety situations on conspiracy thinking, Current Psychology 32, 2013, s. 100-118, VAN PROOIJEN, Jan Willem - ACKER, Michele: The influence of control on belief in conspiracy theories: Conceptual and applied extensions, Applied Cognitive Psychology 29, 2015, s. 753-761.
} 
would become one of the pillars of the pseudoscientific theory of Great Lechia, which has been gaining popularity in recent years.

Although the "theory" of Great Lechia and the issue of "turbo-slavs" is interesting by itself, the author puts forward the argument that above mentioned issues have a lot in common with so-called "conspiracy theories" and are not only problems by themself, but also a symptoms of a deeper problems afflicting modern society. All this means that combating pseudoscientific theories, not only in field of history, is very difficult, and the solutions currently proposed are likely to be insufficient. 